\title{
MONETARY POLICY MODEL FOR OPEN ECONOMY OF INDONESIA
}

\author{
Umar Juoro'
}

\begin{abstract}
This paper explains stylized facts about the monetary economy in Indonesia covering the Bank Indonesia (BI) policy on the exchange rate, lending rates, inflation, real effective rate (REER), and growth. This is done to get an understanding on the impact of foreign policy (influenced by the Fed) on Indonesia's monetary economy, with some attention to the fund rate. An empirical model of VAR Vector Auto Regression) was developed to capture the impact of an increase in fund rate to Indonesia's monetary sector. Furthermore, a theoretical model was developed to capture the result from empirical model. The theoretical model shows that the increase of fund rate influenced the increase of BI rate, lending rate, inflation, while reducing REER and growth.
\end{abstract}

Keyword: monetary policy, lending rate, inflation, exchange rate.

JEL Classification: E52, F41

1 Author is Chairman of Supervisory Board of Bank Indonesia (BSBI) and is Senior Economist at CIDES (Center for Information and Development Studies). Corresponding author: juoro@indo.net.id. We thank to Abdul Manap Pulungan for his excellent research assistance. 


\section{INTRODUCTION}

Indonesia's monetary policy is focused on inflation. Not with standing, the foregoing aspects of growth remains a concern. With an open economy, monetary policy also has implications for the exchange rate. On this regard, monetary policy by raising or lowering the $\mathrm{BI}$ not only will affect inflation, but also economic growth and exchange rate.

The main developments in the monetary sector of Indonesia in the period 2000-2013 can be described in five observations (or stylized facts). First, in July 2005 the BI rate was employed as an instrument of monetary policy, which also set inflation as the goal of monetary policy. Second, high inflation in 2005 resulted in a price hike of more about 130\%, leaded the central bank to raise his rate as high as $12.75 \%$ in December 2005. Third, the global financial crisis in December 2008 forced the central bank to raise the BI rate at the level of $9.50 \%$, following previous declining trend in 2006-2007. Fourth, the period 2010-2012 showed loose monetary policy, with the lowest BI rate followed by the lowest lending rate in Indonesian economic history. Fifth, an increase in the $\mathrm{BI}$ rate as response against the stimulus reduction (tapering) of the Federal Reserve in June of 2013. Sixth, lending rate quickly response to the increase in BI rate, but decrease slowly as the BI rate was lowered.

The development of the real exchange rate (REER) is strongly associated with inflation and the funds rate. At the time of high inflation and funds rate, the REER has depreciated, as in 2001, and 2008. At the time of low inflation and low funds rate, the REER appreciated, as in the years 2009-2012 (Figure 1).

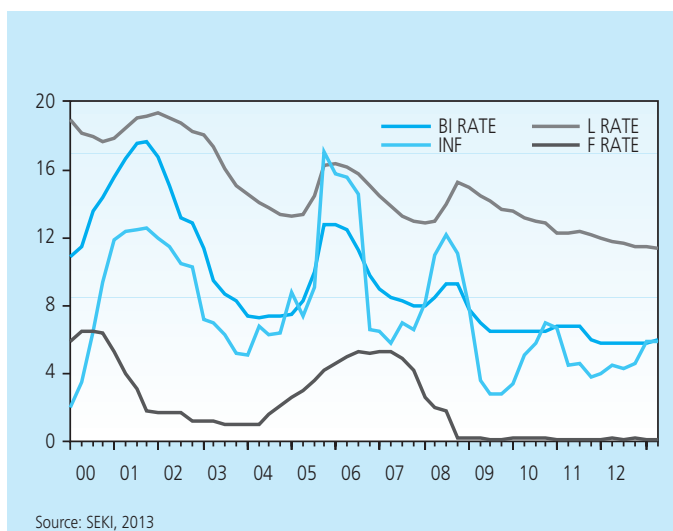

Figure 1.

The development of the $\mathrm{BI}$ rate, lending rate, Inflation, and the Fed Funds Rate

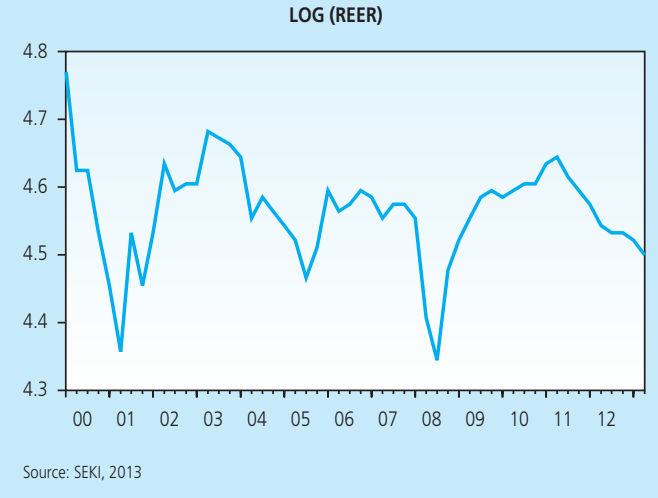

Figure 2.

The development of the Real Effective Exchange Rate (REER) and Nominal Effective Exchange Rate (NEER) in the log 


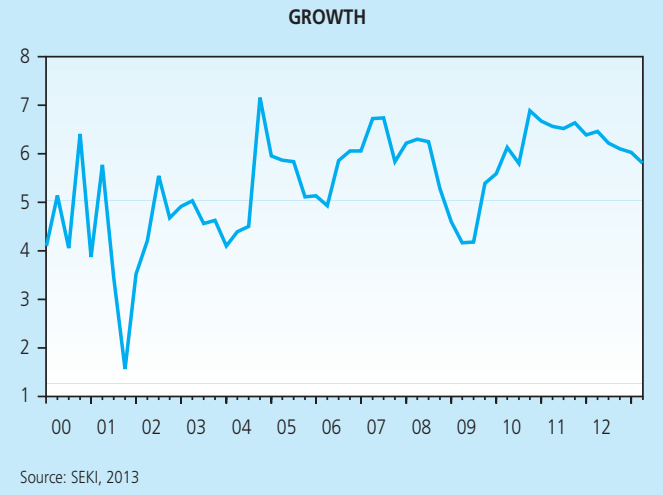

Figure 3.

Indonesia's Economic Growth 2000-2012

In relation to inflation, high economic growth corresponds with a low inflation rate. This high growth rate also occurs when the funds rate and BI rates are low (also funds rate), as was the case in 2000, 2004 and 2010. In contrast, when the BI (and the funds rate) were high, growth declined sharply during the high inflation, such as in 2001 and 2008 (Figure 3).

Empirical picture above shows that the monetary policy conducted by Bank Indonesia, had an influence on the economy. Thus measuring the impact of monetary policy is necessary to consider various factors outside the correlative relationship of the two directions above. This is the underlying premise of the research outlined in this paper.

The second part of this paper reviews the theoretical models of monetary policy in an open economy, within the context of the Indonesian economy. The model used adopts the stickiness of prices (price rigidities), the premise that price adjustment takes time, Taylor 's rule, where monetary policy is the main target although inflation is also considered along with the growth and development of endogenous technology in improving productivity through a reduction in the marginal cost. By using computational methods of the program MATLAB, the IRF can be obtained from the theoretical model, and is contrasted with empirical VAR models which is reviewed in the third section The fourth section of this paper presents the results and analysis, while the fifth section provides the conclusions and policy implications.

\section{THEORY}

\section{Model Set Up}

To develop a model of monetary policy that captures the empirical analysis of monetary policy in an open economy, the model was adopted from Monacelli (2005) which was further 
modified by Kuang Tai Ho (2008) to adapt to the characteristics of economic, Indonesia.

This theoretical model to maximize household utility function is as follows:

$$
\mathrm{E}_{0} \sum_{\mathrm{t}=0}^{\mathrm{t}=\infty} \beta^{\mathrm{t}} \mathrm{U}\left(\mathrm{C}_{\mathrm{t}}\right), \mathrm{N}_{\mathrm{t}}
$$

where $\mathrm{N}_{t}$ is the work time, $\mathrm{C}_{t}$ is a composite index of household consumption. Maximizes household utility is faced with budget constraints, wages, and portfolio and transfer taxes greater than the expenditure of domestic and imported goods. In the meantime, companies face a stiff price (price rigidities) as formulated by Calvo (1983). The next specification is domestic inflation, REER, cover interest rate parity, and technology. The production function is

$$
Y_{i}(j)=A_{i} N_{t}(j)
$$

where $a_{t}=\log \left(A_{t}\right)$ follows the process $A R(1)$

To get the dynamic balance model of a small open economy with a flexible exchange rate, it is necessary to lower the 22 equations with 22 variables. The equation for the domestic economy consists of market clearing, the terms of trade - REER, Philipps curve, marginal cost, complete market (linking domestic and international), uncovered interest parity, monetary policy (Taylor's rule), inflation producer, output gap, surprise (shock) productivity, monetary shock, and the shock of exchange rate stabilization. Meanwhile, the international economy is a function of aggregate demand specifications, the aggregate supply curve, marginal cost, monetary policy (Taylor's rule), the output gap, productivity shock and monetary shock.

\section{Calibration and Simulation Models}

Calibration of the model using the scale parameters are presented in Table 1. Basic calibration for each parameter refers to the estimations outside the model, and also refers to

\begin{tabular}{|c|c|c|}
\hline \multicolumn{3}{|r|}{$\begin{array}{c}\text { Table } 1 \\
\text { Parameter Value }\end{array}$} \\
\hline Symbol & Value & Explanation \\
\hline B & 0,99 & Discount factor \\
\hline$\Sigma$ & 1 & Inverse elasticity of intertemporal substitution \\
\hline A & 1,5 & Elasticity of subs. Domestic and foreign good \\
\hline$\Phi$ & 1 & Elasticity of subst. of labor supply \\
\hline$\Phi \pi \mathrm{s}$ & 1,$5 ; 0,5$ & The coefficient of inflation and the output gap in the Taylor rule abroad \\
\hline$\square \mathrm{H}$ & 0,75 & The level of price stickiness \\
\hline$\square$ & 0,65 & Persistence parameters \\
\hline$\Phi$ & 0,1 & Shock (shock) domestic productivity \\
\hline
\end{tabular}
a range of previous studies. 


\begin{tabular}{c|c|l}
\multicolumn{2}{l}{} \\
Symbol & Value & \multicolumn{1}{c}{$\begin{array}{c}\text { Table 1 } \\
\text { Parameter Value }\end{array}$} \\
\hline$\rho_{\mathrm{s}}$ & 0,6 & Foreign productivity shock \\
\hline$\square$ & 0,3 & Part of imported goods \\
\hline$\rho_{\mathrm{r}}$ & 0,38 & Degree of interest rate smoothing domestic, Taylor rule, \\
\hline$\rho_{\mathrm{rs}}$ & 0,8 & Degree of interest rate smoothing foreign, Taylor rule \\
\hline$\Phi_{\pi}$ & 1,2 & Inflation coefficient in the Taylor rule domestic \\
\hline$\Phi_{\mathrm{x}}$ & 0,35 & The coefficient of the output gap in the Taylor rule domestic \\
\hline$\rho_{\mathrm{z}}$ & 0,9 & Domestic productivity shock \\
\hline$\rho_{\mathrm{zs}}$ & 0,9 & Foreign productivity shock \\
\hline$\rho_{\mathrm{q}}$ & 0,6 & Stability of the exchange rate shock \\
\hline
\end{tabular}

Figure 4 (a) shows the increase in the BI rate (25 bps) above the steady state which causes an increase in lending rates by 20 bps above the steady state and gradually returns to a steady state. Inflation, and economic growth decreases, and gradually returns to a steady state. Inflation was back in two quarters and REER in 7 quarters to steady state. ${ }^{2}$

Figure 4 (b) shows the exchange rate stabilization can quickly stabilize inflation, interest on a loan, and the exchange rate back to a steady state in just two quarters, and with positive economic growth.
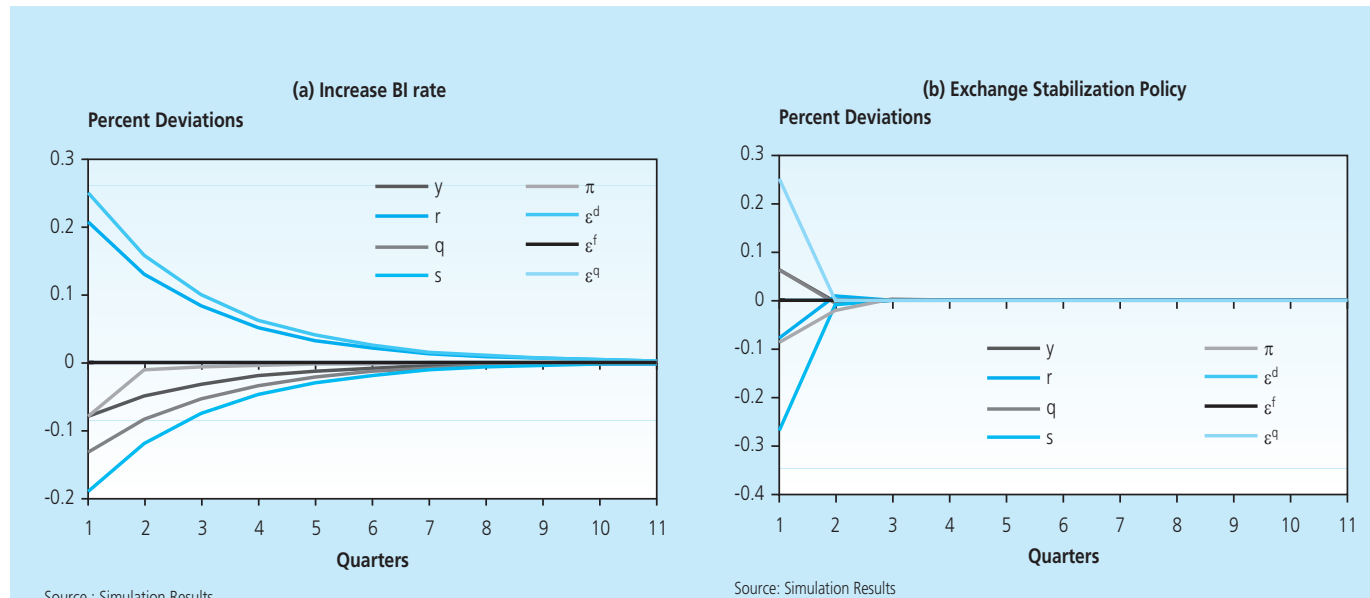

Figure 6.

The increase in the BI policy rate and funds rate and Implications to Economic and Exchange Rate Stabilization Policy

2 Chapter IV analyzes the results and it will be shown that these results are similar to the results of the VAR model used. 


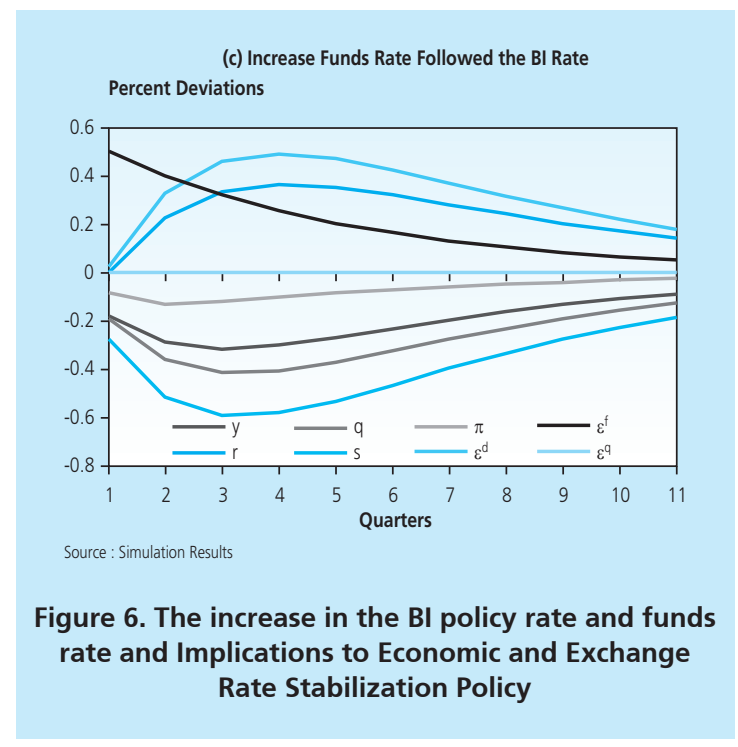

Figure 4 (c) shows that the increase in the funds rate followed by a rise in borrowing raised the $\mathrm{BI}$ rate, but lowered inflation, growth and the REER. Exchange rate took a longer time to move back to the steady state than if only there was a BI rate hike. There was also no increase in funds rate.

Figure 5 (a) shows the stimulative monetary policy by lowering the BI rate (25 bps) from the steady state which is immediately followed by a decrease in interest on loans, rising inflation, REER, and growth. Figure 5 (b) shows a decrease in the funds rate followed by a decrease in

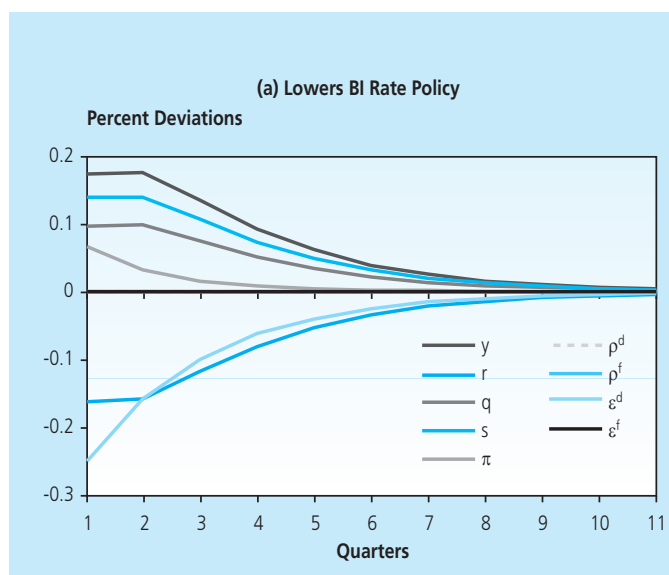

Source: Simulation Results

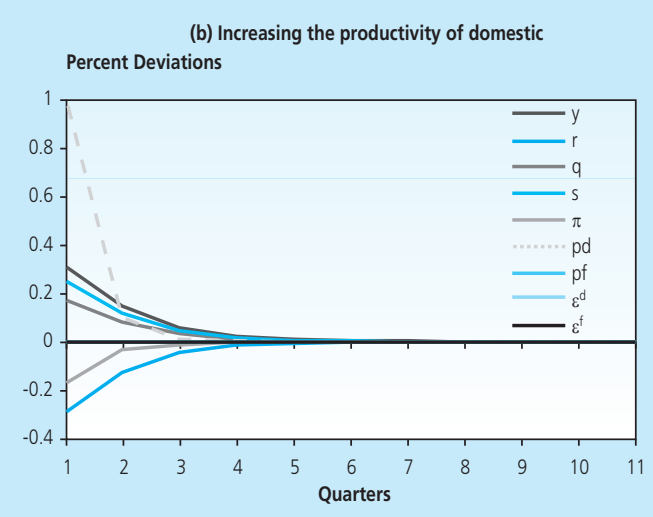

Source: Simulation Results

Figure 5.

Monetary Policy Stimulus Model Form of the BI Rate to the Economy and the Economic Decline of the Funds rate compared with Increased Productivity 
(c) The policy followed fundrate decrease BI Rate Percent Deviations

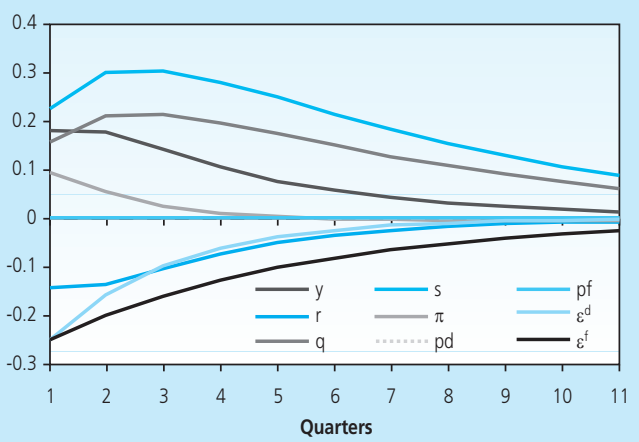

Source: Simulation Results

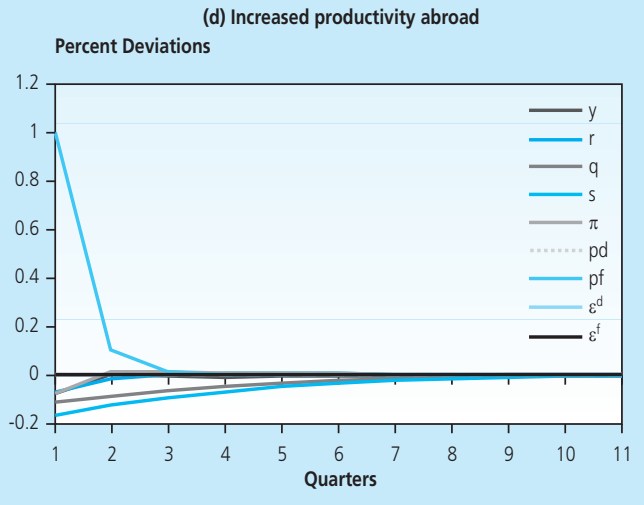

Source: Simulation Results

Figure 5.

Monetary Policy Stimulus Model Form of the BI Rate to the Economy and the Economic Decline of the Funds rate compared with Increased Productivity

the $\mathrm{BI}$ rate and increase domestic economic growth. Meanwhile, the loan interest, inflation, and the REER had increased.

Figure 5 (c) shows an increase in domestic productivity, and increased growth higher than the decrease in BI Rate. Inflation and interest on loans decreased, while the REER rose. Figure 5 (d) shows an increase in productivity abroad had a negative effect on the domestic economy with declining growth, while inflation, interest on loans, and REER were lower.

\section{METHODLOGY}

VAR model assumes Indonesian economy can be explained by the following structural equation:

$$
\mathrm{A}(\mathrm{L}) \mathrm{Y}_{\mathrm{t}}=\mathrm{B}(\mathrm{L}) \mathrm{X}_{\mathrm{t}}+\varepsilon_{\mathrm{t}}
$$

$A(L)$ is the polinominal matrix $n \times n$ is the operator lag, and $B(L)$ is the polinominal matrix $\mathrm{n} \times \mathrm{k}$ with the operator lag. $\mathrm{Y}_{\mathrm{t}}$ is the endogenous variable that consists of $\mathrm{g}_{\mathrm{t}}$ is economic growth, $\varpi_{t}$ is inflation, $q_{t}$ is log (REER), $b r_{t}$ is the $B I$ rate, and $f_{t}$ is the fund rate. $X_{t}$ is $k x 1$ vector of exogenous overseas variables (fund rate), $\varepsilon_{\mathrm{t}}$ is the vector of structural distribution $\mathrm{n} \times 1$, where $\operatorname{var}\left(\varepsilon_{t}\right)=\Omega$ which is the diagonal matrix.

To determine the implications of monetary policy abroad (the Fed) the Indonesian economy, then the next VAR model is in the form of a first-order VAR is: 


$$
A\left[\begin{array}{l}
g_{t} \\
\pi_{t} \\
q_{t} \\
b r_{t} \\
f r_{t}
\end{array}\right]=B\left[\begin{array}{c}
g_{t-1} \\
\pi_{t-1} \\
q_{t-1} \\
b r_{t-1} \\
f r_{t-1}
\end{array}\right]+\left[\begin{array}{c}
\varepsilon^{g} \\
\varepsilon^{\pi} \\
\varepsilon^{q} \\
\varepsilon^{d} \\
\varepsilon^{f}
\end{array}\right]
$$

identification of the empirical model is done by setting limits to the matrix where $A$ is lower triangular with unit diagonal elements. Because $\mathrm{br}_{\mathrm{t}}$ and $\mathrm{fr}_{\mathrm{t}}$ appear at the bottom of the system, the identification strategy is that the innovation of $\mathrm{BI}$ rate $\left(\varepsilon_{\mathrm{t}}{ }^{\mathrm{d}}\right)$ and the innovation fund rate $\left(\varepsilon_{t}^{f}\right)$ effect the domestic endogenous variables with one period lag.

Another limitation is that the estimated VAR system is $\mathrm{fr}_{\mathrm{t}}$ follows the simple univariate process $A R(1)$. The Simple univariate process is to set limits $A_{51}=B_{51}=0$, for all $i$ that are not the same as 5 . The purpose of adopting this limitation is due to the assumption that disorder from developing countries, in this case Indonesia, has a very small effect on the major nations such as the U.S.

\section{ANALYSIS AND RESULTS}

The following section will present the results of the estimation model described in the previous section.

\subsection{Impulse Response Function}

Figure 6 presents the impulse response function of a surprise increase in the BI rate. This figure shows that the $\mathrm{BI}$ rate hike was followed by a rise in lending rates (Irate). The increase in the $\mathrm{BI}$ rate to reduce inflation (inf) was done only after the third-quarter (lag) and the back to steady state after eight quarters (lag). The REER raised the BI rate hike back to the steady state only after the three quarters (lag). The BI rate hikes reduced economic growth. So the BI rate hike was quickly followed by a rise in lending rates and a lowering of economic growth with declining consumption. Meanwhile, the decline in inflation and a strengthening in currency took time to be effective (lag) .

While the increase in the funds rate was immediately followed by an increase in the BI rate, interest loans, and inflation (with a lag). The increase in funds rate also implied a weakening of the exchange rate and the decline in economic growth (with a lag). This is understandable because of the increase in funds rate was followed by an increase in the BI rate which has implications for the endogenous variables (Figure 7). 
Response of BIRATE to BIRATE

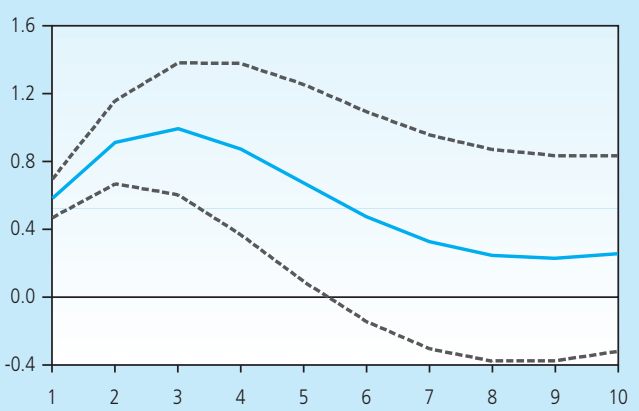

Response of INF to BIRATE

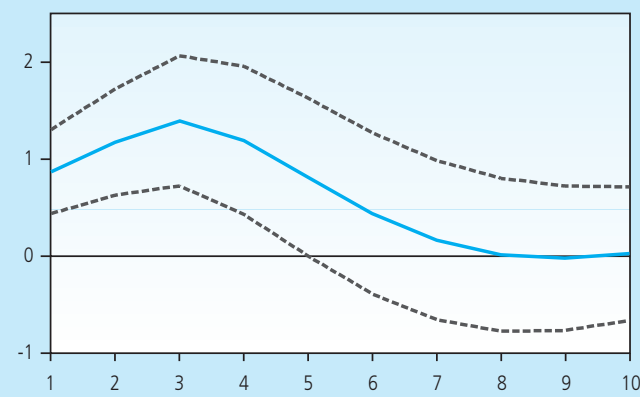

Response of LRATE to BIRATE

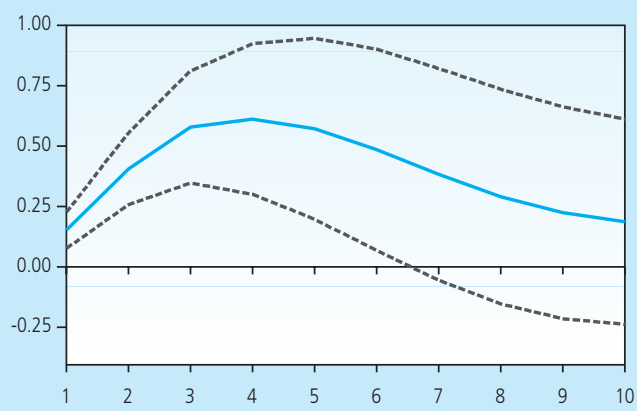

Response of LOG(REER) to BIRATE

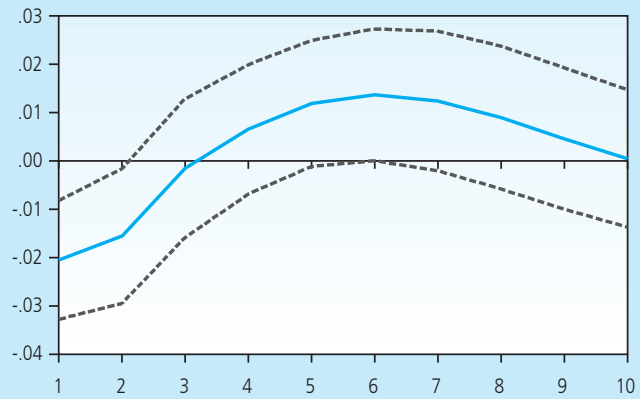

Response of GROWTH to BIRATE

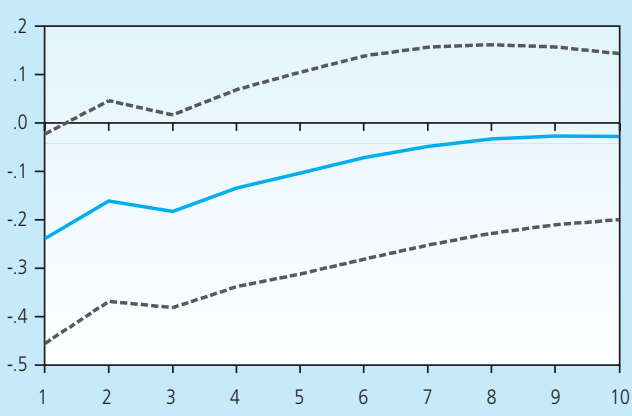

Figure 6.

Variable response to the increase in the BI rate with the exogenous variables Funds Rate 

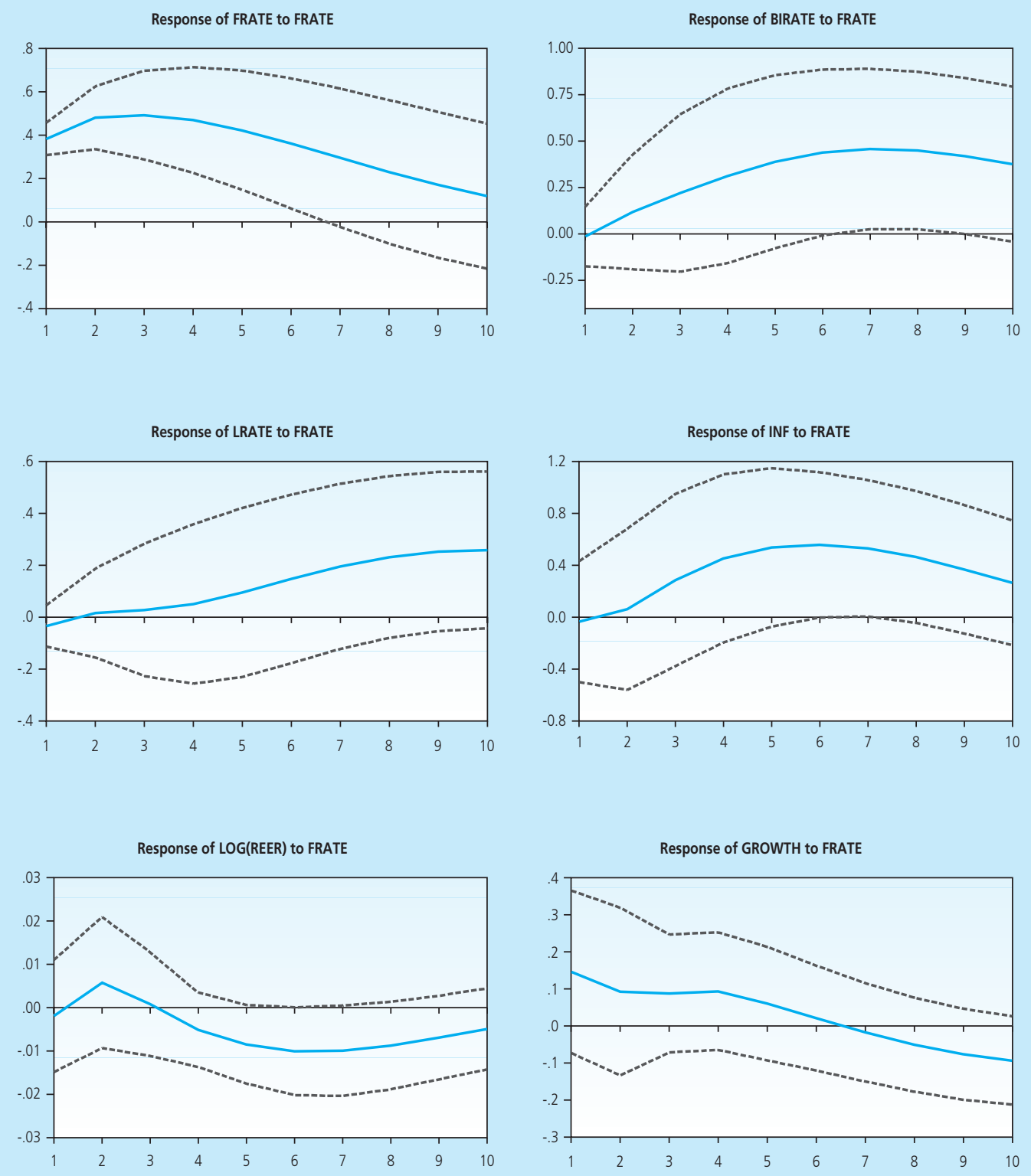

Figure 7.

Impluse response function increased funds rate to endogenous variables 


\subsection{Granger Causality Test}

The Granger Causality Test was used to determine the variables affecting other variables (Table 1). From the estimation results, by examining the t-statistics, it appears that inflation affects the $\mathrm{BI}$ rate, where the $\mathrm{BI}$ rate and the central bank lending rate affect each other; and the central bank inflation rate affects the BI rate and the REER; the BI rate affects the growth, the funds rate affects inflation, as well as the REER. The REER affects lending and growth, and the lending and growth affects each other.

\begin{tabular}{|c|c|c|c|}
\hline \multicolumn{4}{|c|}{$\begin{array}{c}\text { Table } 2 \\
\text { Granger Causality Test }\end{array}$} \\
\hline \multicolumn{4}{|l|}{ Sample: 2000Q1 2013Q2 } \\
\hline \multicolumn{4}{|l|}{ Lags: 2} \\
\hline Null Hypothesis: & Obs & F-Statistic & Prob. \\
\hline $\begin{array}{l}\text { FRATE does not Granger Cause BIRATE } \\
\text { BIRATE does not Granger Cause FRATE }\end{array}$ & 52 & $\begin{array}{l}3.21691 \\
0.08269\end{array}$ & $\begin{array}{l}0.0490 \\
0.9208\end{array}$ \\
\hline $\begin{array}{l}\text { LRATE does not Granger Cause BIRATE } \\
\text { BIRATE does not Granger Cause LRATE }\end{array}$ & 52 & $\begin{array}{l}2.50859 \\
9.70918\end{array}$ & $\begin{array}{l}0.0922 \\
0.0003\end{array}$ \\
\hline $\begin{array}{l}\text { INF does not Granger Cause BIRATE } \\
\text { BIRATE does not Granger Cause INF }\end{array}$ & 52 & $\begin{array}{l}3.09954 \\
7.98482\end{array}$ & $\begin{array}{l}0.0544 \\
0.0010\end{array}$ \\
\hline $\begin{array}{l}\text { LOG(REER) does not Granger Cause BIRATE } \\
\text { BIRATE does not Granger Cause LOG(REER) }\end{array}$ & 52 & $\begin{array}{l}7.39518 \\
1.38538\end{array}$ & $\begin{array}{l}0.0016 \\
0.2603\end{array}$ \\
\hline $\begin{array}{l}\text { GROWTH does not Granger Cause BIRATE } \\
\text { BIRATE does not Granger Cause GROWTH }\end{array}$ & 52 & $\begin{array}{l}1.10661 \\
3.08633\end{array}$ & $\begin{array}{l}0.3391 \\
0.0550\end{array}$ \\
\hline $\begin{array}{l}\text { LRATE does not Granger Cause FRATE } \\
\text { FRATE does not Granger Cause LRATE }\end{array}$ & 52 & $\begin{array}{l}0.16020 \\
1.89368\end{array}$ & $\begin{array}{l}0.8524 \\
0.1618\end{array}$ \\
\hline $\begin{array}{l}\text { INF does not Granger Cause FRATE } \\
\text { FRATE does not Granger Cause INF }\end{array}$ & 52 & $\begin{array}{l}0.57138 \\
3.50136\end{array}$ & $\begin{array}{l}0.5686 \\
0.0382\end{array}$ \\
\hline $\begin{array}{l}\text { LOG(REER) does not Granger Cause FRATE } \\
\text { FRATE does not Granger Cause LOG(REER) }\end{array}$ & 52 & $\begin{array}{l}0.26765 \\
2.93240\end{array}$ & $\begin{array}{l}0.7663 \\
0.0631\end{array}$ \\
\hline $\begin{array}{l}\text { GROWTH does not Granger Cause FRATE } \\
\text { FRATE does not Granger Cause GROWTH }\end{array}$ & 52 & $\begin{array}{l}1.10998 \\
1.89279\end{array}$ & $\begin{array}{l}0.3380 \\
0.1620\end{array}$ \\
\hline
\end{tabular}




\begin{tabular}{|c|c|c|c|}
\hline \multicolumn{4}{|c|}{$\begin{array}{c}\text { Table } 2 \\
\text { Granger Causality Test }\end{array}$} \\
\hline Sample: 2000Q1 2013Q2 & & & \\
\hline \multicolumn{4}{|l|}{ Lags: 2} \\
\hline Null Hypothesis: & Obs & F-Statistic & Prob. \\
\hline $\begin{array}{l}\text { INF does not Granger Cause LRATE } \\
\text { LRATE does not Granger Cause INF }\end{array}$ & 52 & $\begin{array}{l}0.32414 \\
2.58781\end{array}$ & $\begin{array}{l}0.7248 \\
0.0859\end{array}$ \\
\hline $\begin{array}{l}\text { LOG(REER) does not Granger Cause LRATE } \\
\text { LRATE does not Granger Cause LOG(REER) }\end{array}$ & 52 & $\begin{array}{l}17.2285 \\
0.73871\end{array}$ & $\begin{array}{l}2 . E-06 \\
0.4832\end{array}$ \\
\hline $\begin{array}{l}\text { GROWTH does not Granger Cause LRATE } \\
\text { LRATE does not Granger Cause GROWTH }\end{array}$ & 52 & $\begin{array}{l}0.26624 \\
4.86701\end{array}$ & $\begin{array}{l}0.7674 \\
0.0120\end{array}$ \\
\hline $\begin{array}{l}\text { LOG(REER) does not Granger Cause INF } \\
\text { INF does not Granger Cause LOG(REER) }\end{array}$ & 52 & $\begin{array}{l}1.76167 \\
1.04978\end{array}$ & $\begin{array}{l}0.1829 \\
0.3581\end{array}$ \\
\hline $\begin{array}{l}\text { GROWTH does not Granger Cause INF } \\
\text { INF does not Granger Cause GROWTH }\end{array}$ & 52 & $\begin{array}{l}0.50295 \\
1.24195\end{array}$ & $\begin{array}{l}0.6080 \\
0.2981\end{array}$ \\
\hline $\begin{array}{l}\text { GROWTH does not Granger Cause LOG(REER) } \\
\text { LOG(REER) does not Granger Cause GROWTH }\end{array}$ & 52 & $\begin{array}{l}4.03464 \\
2.64905\end{array}$ & $\begin{array}{l}0.0242 \\
0.0813\end{array}$ \\
\hline
\end{tabular}

\subsection{Variance Decompositions}

To understand the contribution of shock increase to the $\mathrm{BI}$ rate and funds rate from the empirical models used, the analysis of variance decomposition of the variables contained in the VAR system of equations (1) and equation (2) was used. Table 1 shows that according to the estimates of the VAR system in equation (1), innovation in the $B I$ rate, $\varepsilon^{d}$, provides approximately $40 \%$ change in the aggregate variables in the Indonesian economy, most of it is inflation and the REER about 15\%, which is relatively low at around $5 \%$ interest on the loan, and the economic growth of about $4 \%$.

Table 3

Sources of shock on Variance decompositions Monetary

\begin{tabular}{l|c|c}
\multicolumn{1}{c|}{ Variable } & BI rate & Fund rate \\
\hline BI rate & $61.1 \%$ & $23.4 \%$ \\
\hline Inflation & $14.8 \%$ & $4.8 \%$ \\
\hline REER & $14.6 \%$ & $4.3 \%$ \\
\hline Interest on Loans & $5.4 \%$ & $12.3 \%$ \\
\hline Growth & $4.1 \%$ & $12.8 \%$ \\
Source: Processed Data & &
\end{tabular}


Table 3 shows that the VAR model based on the estimation of equation (2), where innovations in the funds rate, $\varepsilon^{\dagger}$, provides approximately $58 \%$ aggregate changes in the Indonesian economy, mostly in the $\mathrm{BI}$ rate about $23 \%$, then approximately $13 \%$ growth, and about $12 \%$ interest on the loan. Meantime, the influence of inflation and the REER is relatively low. This finding is surprising because it was an external shock that was greater than internal shocks to the Indonesian economy. The explanation is that the Indonesian economy is very open to external shocks, in this case the funds rate, greatly affected the flow of capital in and out of Indonesia. This influence was also felt for growth.

\section{CONCLUSION}

From the observations (stylized facts), the empirical VAR models and the theoretical models, it is clear that the Fed 's monetary policy of raising or lowering the funds rate has a major impact on the Indonesian economy. The increase in funds rate is followed by an increase in the BI rate, then interest on the loan, the decline in inflation and economic growth with a delay (lag). The decline in growth is greater when the fund rate and $\mathrm{BI}$ rate hikes together, compared to when only the $\mathrm{BI}$ rate is raised. The REER takes a long time (lag) to return to a steady state. Exchange rate stabilization policy can bring down inflation and strengthen the REER quickly, and induce positive economic growth. Theoretical models according to the empirical VAR models, increase in inflation in the empirical models, while the theoretical models of inflation decreases inflation when there is an increase in the funds rate.

The theoretical models that captured the empirical models performed well enough where the funds rate decreased, which was followed by a decline in the BI rate resulting in a lowering and raising of lending rates of economic growth, and the REER. But inflation also increased. The increase in domestic productivity growth is higher than the decrease in the $\mathrm{BI}$ rate, amid declining inflation and appreciating REER. While the increase in productivity abroad has negative implications on the domestic economy in lowering growth and weakening the REER, inflation is decreased. 


\section{REFERENCES}

Bank Indonesia, 2013, Statistik Ekonomi dan Keuangan Indonesia, dalam http://www. bi.go.id/web/id/Statistik/Statistik+Ekonomi+dan+Keuangan+Indonesia/Versi+HTML/ Sektor+Moneterl, diakses 20 September 2013

Calvo, G. 1983, "Staggered Prices in a Utility Maximizing Framework", Journal of Monetary Economics, 12:383-398

Gali, J. dan T. Monacelli,2005, "Monetary Policy and Exchange Rate Volatility in a Small Open Economy", Review of Economics Studies, 72: 707-734.

Ho, T. H, 2009, "Derivation of Monacelli (2005) Small Open Economy Model", Manuscript. National Tsing Hua Univerisity, Taiwan.

Martens, K. 2013, "Macroeconomic Theory: Money and Output", Manuscript, Cornell University.

Obstsfeld, M. and Rogoff, K. 2007, Foundations of International Macroeconomics, Cambridge, MA: MIT Press

Vegh, C. 2013, Open Economy Macroeconomics in Developing Countries. Cambridge, MA: MIT Press. 